\title{
Assessment of Gaseous and Particulate Pollutants in the Ambient Air in Al Mirfa City, United Arab Emirates
}

\author{
Entisar Al Katheeri, Fadi Al Jallad, Muthanna Al Omar
}

National Energy and Water Research Centre, Abu Dhabi Water and Electricity Authority, Abu Dhabi, UAE.

Email: eakatheeri@adwea.ae

Received March 16 ${ }^{\text {th }}, 2012$; revised April 17 ${ }^{\text {th }}, 2012$; accepted May $20^{\text {th }}, 2012$

\begin{abstract}
From 2007-2009, National Energy and Water Research Center (NEWRC) on behalf of Abu Dhabi Water and Electricity Authority (ADWEA) conducted a long term baseline study of nitrogen dioxide $\left(\mathrm{NO}_{2}\right)$, carbon monoxide $(\mathrm{CO})$, sulfur dioxide $\left(\mathrm{SO}_{2}\right)$, ozone $\left(\mathrm{O}_{3}\right)$ and particulate matter $<10 \mu \mathrm{m}$ in diameter $\left(\mathrm{PM}_{10}\right)$ using ambient air quality station located in the vicinity of Al Mirfa power plant in Abu Dhabi, United Arab Emirates (UAE). The objective of this study was to establish baseline levels and study the behavior of airborne pollutants from natural as well as anthropogenic origins with temporal variations. The study reveals that the average hourly values for $\mathrm{NO}_{2}, \mathrm{SO}_{2}$, and 8 hour average of $\mathrm{CO}$ were within the acceptable levels of 400,300 and $30,000 \mu \mathrm{g} / \mathrm{m}^{3}$ respectively, whereas the levels of $\mathrm{O}_{3}$ as 8 hour average $\left(<200 \mu \mathrm{g} / \mathrm{Nm}^{3}\right)$ and PM10 $\left(<150 \mu \mathrm{g} / \mathrm{Nm}^{3}\right)$ occasionally exceeded the FEA permissible limits during the study period. Seasonal variation based on three years data reveals that the highest concentration of $\mathrm{NO}_{2}$ and $\mathrm{SO}_{2}$ were during winter and for $\mathrm{CO}$ and $\mathrm{O}_{3}$ during summer months. Results indicate that the levels of $\mathrm{SO}_{2}$ and $\mathrm{CO}$ were significantly controlled and improved while the fuel combustion of Al Mirfa power plant had increased from 2007 to 2009. Dust has significantly impact on the air quality by elevated levels of $\mathrm{PM}_{10}$ exceed in several instances associated with regional sandstorm during the monitoring period.
\end{abstract}

Keywords: Ambient Air Quality Monitoring; Seasonal Variations; Sandstorm

\section{Introduction}

Abu Dhabi, the capital of UAE lies on a T-shaped island jutting into the Arabian Gulf from the central western coast. Rapid economic, industrial, and population growth in the UAE for the past 40 years has led to the burning of more fossil fuel for power generation and subsequent releases of air pollutants into the air environment. Air pollutants that have been identified as an indicator of air quality by the United States Environmental Protection Agency (USEPA) are nitrogen oxides $\left(\mathrm{NO}_{2}\right)$, sulphur oxides $\left(\mathrm{SO}_{2}\right)$, carbon monoxides $(\mathrm{CO})$, ozone $\left(\mathrm{O}_{3}\right)$, particulate matter $\left(\mathrm{PM}_{10}\right)$ and lead $(\mathrm{Pb}) . \mathrm{SO}_{2}, \mathrm{NO}_{2}, \mathrm{CO}$ and $\mathrm{PM}_{10}$ are well recognized as sources emitted from the combustion of fuels used in power and desalination plants. The impact of emissions from power generation plants on ambient air quality that cause air pollution has been an area of concern and a focus of study during recent years [1]. Therefore, ambient air monitoring of potentially harmful levels of pollutants is of paramount importance. The attention to the exposure to elevated pollutants concentrations for long continued exposure has increased due to wide range of adverse effects of air pollutants on ecological system and human health [2-4].
The impact of power generation on ambient air quality has been investigated by many authors including the role of power generation in air pollution [5]. Despite knowing that the anthropogenic ambient air pollution, in particular particulate matter (PM), causes a considerable public health impact in the UAE in terms of premature deaths as major causes [6], the studies on air quality monitoring are restricted to few. An author reported air pollutants, $\mathrm{H}_{2} \mathrm{~S} . \mathrm{NO}_{\mathrm{X}}, \mathrm{NO}_{2}, \mathrm{NO}, \mathrm{SO}_{2}, \mathrm{O}_{3}, \mathrm{CO}$, and $\mathrm{HC}$, at various locations in Bahrain and found that most pollutants are at lower levels compared with standards [7]. In Al Mirfa City, located in the western region of Abu Dhabi, UAE, a power generation and desalination plant provides the local populace with electricity and water. Air emissions (solid or liquid particles and gases) contaminate the environment and result in chronic (arising from long-term exposure) or acute (due to accidents) health consequences on living populations and the ecosystem. This research study was conducted to determine the levels of $\mathrm{SO}_{2}, \mathrm{NO}_{2}, \mathrm{CO}, \mathrm{O}_{3}$ and $\mathrm{PM}_{10}$ in the vicinity of Al Mirfa power plant and whether the levels of any of these pollutants exceeded permissible limits as specified by the laws of the UAE Federal Environment Agency [8] 
Table 1. Ambient air quality standards stated by UAE-FEA, along with the detection principle for each pollutant.

\begin{tabular}{|c|c|c|c|}
\hline Substance & Max. Allowable Limits $\left(\mu \mathrm{g} / \mathrm{Nm}^{3}\right)$ & Avg. Time & Experimental Method \\
\hline \multirow{3}{*}{ Sulfur Dioxide } & 350 & 1 hour & \multirow{3}{*}{ UV fluorescence } \\
\hline & 150 & 24 hour & \\
\hline & 60 & 1 year & \\
\hline \multirow[b]{2}{*}{ Carbon Monoxide } & $30\left(\mathrm{mg} / \mathrm{Nm}^{3}\right)$ & 1 hour & \multirow[b]{2}{*}{ Non-dispersive infra-red } \\
\hline & $10\left(\mathrm{mg} / \mathrm{Nm}^{3}\right)$ & 8 hour & \\
\hline \multirow{2}{*}{ Nitrogen Dioxide } & 400 & 1 hour & \multirow{2}{*}{ Chemiluminescence } \\
\hline & 150 & 24 hour & \\
\hline \multirow{2}{*}{ Ozone } & 200 & 1 hour & \multirow{2}{*}{ UV Photometry } \\
\hline & 120 & 8 hour & \\
\hline Particulate Matter & 150 & 24 hour & Beta attenuation \\
\hline
\end{tabular}

$\mu \mathrm{g}$ : microgram; mg: milligram; $\mathrm{Nm}^{3}$ : Normal cubic meter.

(Table 1) in addition to identify impact of regional sandstorm on $\mathrm{PM}_{10}$ in Al Mirfa (Figure 1).

\section{Pollution Sources}

Major pollution source in the study area is Mirfa plant which is located about $4 \mathrm{~km}$ upwind of town, and equipped with four gas turbines that each has a capacity of $48 \mathrm{MW}$. The plant consists of 12 stacks with an average height of $60 \mathrm{~m}$ from the ground level. The facility also has a distillation plant with a maximum capacity of 37.7 million gallons per day (MGD). The distillation plant runs continuously on natural gas and occasionally on fuel oil. In 2008, the plant burned 18,090 MSCFof gas and 14,238 gallons of fuel oil [7].

\section{Measurements Techniques}

Ambient Air Monitoring station (AQMS) provided with

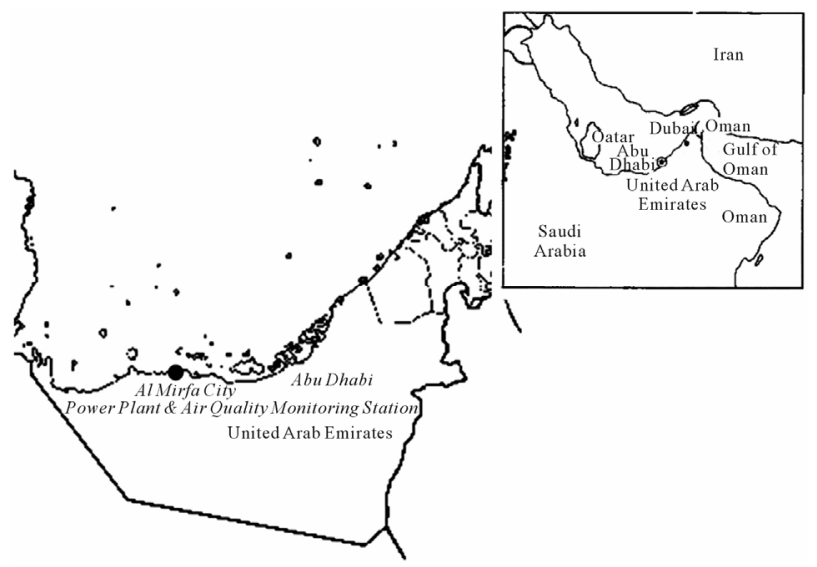

Figure 1. Location of ambient air quality monitoring station in Al Mirfa city, United Arab Emirates. continues gas and particulate monitors along with meteorological sensors for automatic operation and measurements. Five minutes average values are logged continuously for 24 hours a day throughout the year during 2007-2009. Raw data are retrieved simultaneously by advanced central Data Acquisition System (DAS) operated by National Energy and Water Research Center (NEWRC), where rigorous and comprehensive Quality Control/Quality Assurance (QA/QC) programs are implemented to ensure the high quality of collected data which obtained for about $90 \%$ of the study period. Table 1 summarizes the principle of operation for the ambient air quality monitoring.

\section{Characteristic of Air Quality Parameters}

The need to investigate ambient air quality appears paramount especially when bearing in mind the environmental impacts of air pollutants from major air emission sources that can affect local and regional air quality. The dispersion and ground level concentrations of these emissions are determined by a complex interaction of the physical characteristics of plant stacks, physical, chemical characteristics of the emissions, meteorological conditions at or near the site during the time the emissions travel from the stack to the ground level receptor, topographical conditions of the plant site and surrounding areas, and the nature of receptors (e.g. people, agriculture, and vegetation). Fast economic development and growth congregated in Abu Dhabi from past four decades leading to more fossil fuel consumption and subsequently to considerable release of air pollutants. Data from Al Mirfa power plant shows considerable increase in fuel consumption from 2005-2009. During normal operation conditions the fuel used in Al Mirfa plant contains $5 \mu \mathrm{g} / \mathrm{l}$ 
of sulfur. Air pollutants that have been used as indicators of air quality identify six pollutants namely as Nitrogen oxides $\left(\mathrm{NO}_{\mathrm{X}}\right)$, Sulfur oxides $\left(\mathrm{SO}_{\mathrm{X}}\right)$, Carbon monoxide $(\mathrm{CO})$, Ozone $\left(\mathrm{O}_{3}\right)$, Particulate matter $\left(\mathrm{PM}_{10}\right)$ and lead $(\mathrm{Pb})$ [9]. The standards for these pollutants are based on criteria related to health and environmental effects. With the exception of $\mathrm{Pb}$ all criteria pollutants are continuously monitored at Al Mirfa AAQM station. However, the ambient concentrations of $\mathrm{Pb}$ is expected to be in extremely low levels since this pollutant is mainly emitted from vehicles which are completely run by unleaded high grade petrol. In air quality research, information on metrological data has significant importance. Dispersion and dissipation of pollutants are usually involve atmospheric mixing, settling and deposition which are greatly affected by the degree of turbulence in air [10] and the latter in turn depend on weather conditions (as temperature and wind speed), the movement of high and low pressure systems and their interaction with the local topography. The annual average values of gaseous pollutants, particulate matter and meteorological recorded in Al Mirfa AAQM during 2007-2009 are described in approaching subsections.

\section{Results and Discussion}

\subsection{Nitrogen Dioxide $\left(\mathrm{NO}_{2}\right)$}

$\mathrm{NO}_{2}$ which produced under high temperature combustion are major criteria pollutants that are precursors to photochemical smog, ozone, and acid formation. $\mathrm{NO}_{2}$ concentrations found to be within all permissible limits (hourly and daily); hourly average concentrations were relatively low during 2007-2009. Variations in $\mathrm{NO}_{2}$ were found in a range of $0.01-118.72 \mu \mathrm{g} / \mathrm{m}^{3}$ with an annual mean value of 12.96, 13.01 and $13.42 \mu \mathrm{g} / \mathrm{m}^{3}$ during 2007, 2008 and 2009 respectively (Table 2). Peak levels were found during winter and spring while the lowest values prevailed during the summer (Figure 2). The mean value of $\mathrm{NO}_{2}$ in winter $\left(14.44 \mu \mathrm{g} / \mathrm{m}^{3}\right)$ showed a $22 \%$ reduction from the summer value $\left(11.12 \mu \mathrm{g} / \mathrm{m}^{3}\right)$. The trend of respective higher and lower values of $\mathrm{NO}_{2}$ during winter and summer could be attributed to an enhanced oxidation process [11], where a reduction in photochemical reactions occur between $\mathrm{NO}_{2}$ and hydroxyl $(\mathrm{OH})$ radicals that form nitric acid $\left(\mathrm{HNO}_{3}\right)$ [12]. This trend was also observed in many studies on ambient air quality monitoring $[11,12]$.

\subsection{Carbon Monoxide (CO)}

CO levels vary within a range of $0.01-5.73 \mathrm{mg} / \mathrm{m}^{3}$ with respective mean values of $0.67,1.09,0.57 \mathrm{mg} / \mathrm{m}^{3}$ during 2007, 2008 and 2009 respectively. Seasonal variation of $\mathrm{CO}$ at the Al Mirfa site exhibited a distinct cycle with maximum values in summer and minimum values in winter. Elevated levels of $\mathrm{CO}$ during summer are attributed to more gas burning in power stations in arid zones due to increased electricity demand used in air-conditioning [13]. As Korean study concluded that there is a close correlation between $\mathrm{CO}$ poisoning and temperature for summer months, and this association was much stronger in August when the temperature was high. However, on contrary to this $\mathrm{CO}$ emissions are sensitive to ambient temperature in cold weather such as Moscow which being higher in winter [11] due to more poisoning of fuel during winter than summer. Hourly and 8-hour rolling averages of $\mathrm{CO}$ concentrations was low comparing with FEA standard allowable limits and neither hourly nor 8-hour limits were violated during the stud period.

\subsection{Sulphur Dioxide $\left(\mathrm{SO}_{2}\right)$}

$\mathrm{SO}_{2}$ concentration was recorded within a range of 0.03 -

Table 2. Annual average concentrations of ambient air pollutants, calculated on hourly values, in Al Mirfa during $2007-2009$.

\begin{tabular}{|c|c|c|c|c|c|}
\hline Pollutant & Unit & Levels & 2007 & 2008 & 2009 \\
\hline \multirow{2}{*}{$\mathrm{NO}_{2}$} & \multirow{2}{*}{$\mu \mathrm{g} / \mathrm{m}^{3}$} & Mean & 12.96 & 13.01 & 13.42 \\
\hline & & Range & $0.00-118.72$ & $0.02-99.14$ & $0.13-92.65$ \\
\hline \multirow{2}{*}{$\mathrm{SO}_{2}$} & \multirow{2}{*}{$\mu \mathrm{g} / \mathrm{m}^{3}$} & Mean & 4.24 & 2.56 & 3.24 \\
\hline & & Range & $0.03-39.22$ & $0.21-84.65$ & $0.05-67.96$ \\
\hline \multirow{2}{*}{$\mathrm{CO}$} & \multirow{2}{*}{$\mathrm{mg} / \mathrm{m}^{3}$} & Mean & 0.67 & 1.09 & 0.57 \\
\hline & & Range & $0.01-3.60$ & $0.09-5.73$ & $0.01-2.06$ \\
\hline \multirow{2}{*}{$\mathrm{O}_{3}$} & \multirow{2}{*}{$\mu \mathrm{g} / \mathrm{m}^{3}$} & Mean & 58.70 & 74.77 & 69.62 \\
\hline & & Range & $0.04-197.73$ & $2.71-274.21$ & $0.20-207.18$ \\
\hline \multirow{2}{*}{$\mathrm{PM}_{10}$} & \multirow{2}{*}{$\mu \mathrm{g} / \mathrm{m}^{3}$} & Mean ${ }^{*}$ & 122 & 155 & 157 \\
\hline & & Range $^{*}$ & $21-1134$ & $12-1002$ & $4-1426$ \\
\hline
\end{tabular}



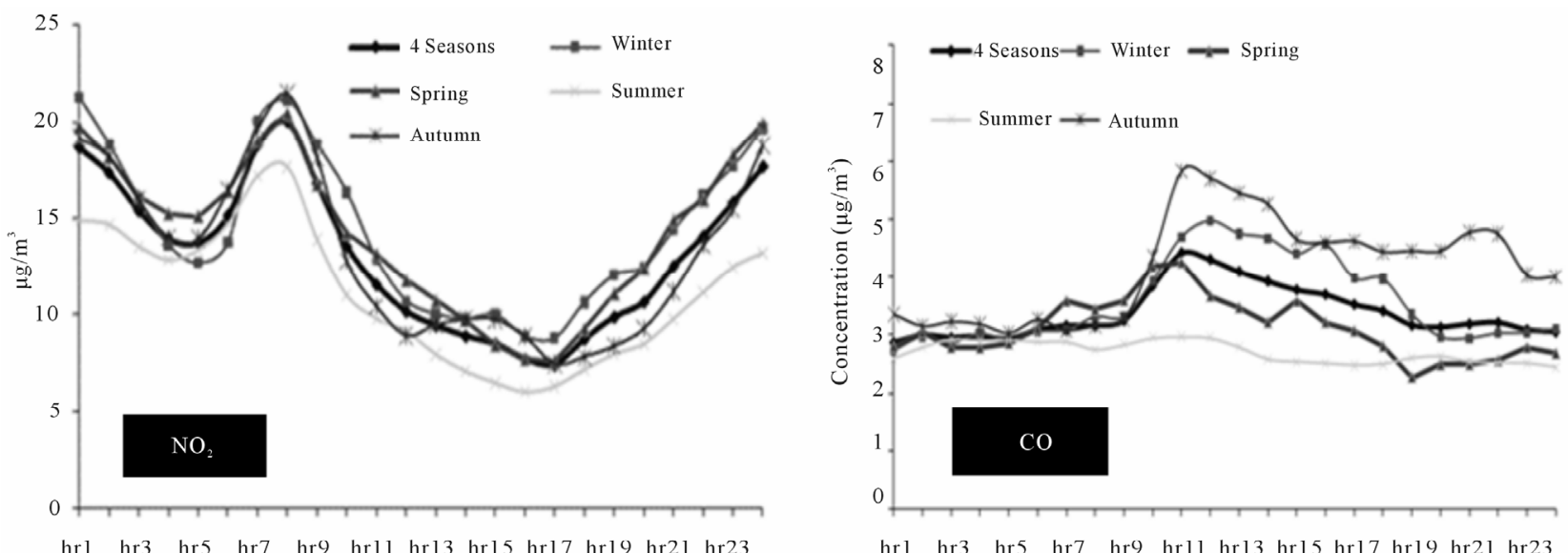
hrl hr3 hr5 hr7 hr9 hrll hrl3 hrl5 hr17 hrl9 hr2l hr23 time
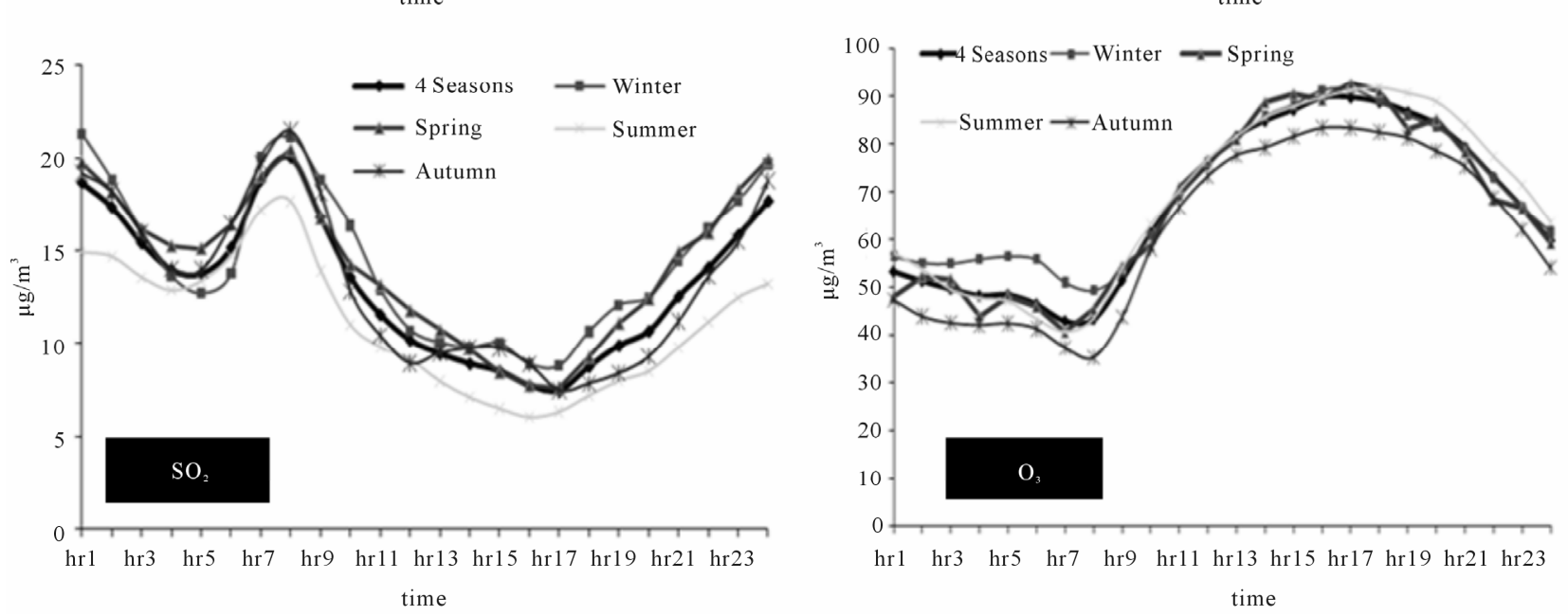

Figure 2. Diurnal and seasonal variations of $\mathrm{NO}_{2}, \mathrm{CO}, \mathrm{SO}_{2}$ and $\mathrm{O}_{3}$ during 2007-2009.

$84.65 \mu \mathrm{g} / \mathrm{m}^{3}$ with a mean value of $4.24,2.56$ and 3.24 $\mu \mathrm{g} / \mathrm{m}^{3}$ during 2007, 2008 and 2009 respectively. $\mathrm{SO}_{2}$ in Al Mirfa was found to be well below the FEA permissible limits. The concentration of $\mathrm{SO}_{2}$ can be increased depending on the nearest source activities such as Industrial and vehicular emissions. However, monitoring showed low concentration values during the study period which can be attributed to the green fuels used in the whole country. Diurnal and seasonal variations can be justified by traffic activity trend near the monitoring location as well as the variations in humidity and air pollution levels throughout the year $\left(\mathrm{SO}_{2}\right.$ reacts with other substances and moisture in the atmosphere to form sulfate aerosols and sulfuric acids). Monitoring results indicate peak concentration of $\mathrm{SO}_{2}$ tends to be in winter months followed by spring and fall months while the minimum concentrations are during summer months that characterized by high humidity conditions. This trend was found to be similar to other studies [12]. Low to medium winds blowing from the direction of power plant towards populated residential area can increase the possibility of pollution. In 2009 , about $49 \%$ of wind speed records were between $0.5-2.9 \mathrm{~m} / \mathrm{s}$.

\subsection{Ozone $\left(\mathrm{O}_{3}\right)$}

Fluctuation in $\mathrm{O}_{3}$ varied in a range $0.04-274.21 \mu \mathrm{g} / \mathrm{m}^{3}$. The mean values of $\mathrm{O}_{3}$ in $\mathrm{Al}$ Mirfa monitoring station were high with respective mean values 58.70, 74.77, $69.62 \mu \mathrm{g} / \mathrm{m}^{3}$ during 2007, 2008 and 2009. During the monitoring period, hourly values were below FEA limits, however, violation of the hourly average standard limit of $200 \mu \mathrm{g} / \mathrm{m}^{3}$ was noticed, nevertheless, it is known that this pollutant is produced throughout complex photochemical reactions of nitrogen oxides and Volatile Organic Compounds (VOCs) in presence of sunlight and it is not directly emitted into the air from any particular activities. Most of the ozone in the troposphere (lower sphere) is formed indirectly by the action of sunlight on nitrogen dioxide. In addition to photo chemical reactions ozone $\left(\mathrm{O}_{3}\right)$ produces a number of oxidants including peroxyacetyl nitrates (PAN), nitric acid and hydrogen per oxide [14]. Diurnal variations attributed to high intensity of sunlight during day time which leads to form high 
ground level of ozone as similar to other studies [15]. Time series of $\mathrm{O}_{3}$ shows statistically significant trend in most cities world-wide [14]. Elevated ground level ozone is expected to be monitored during spring and summer seasons as the sunlight intensifies and start to induce the photochemical reaction Peak $\mathrm{O}_{3}$ levels were seen dependent on seasonal temperatures and observed numbers of sunny days in a particular city besides availability of its precursors. There has been $50 \%-60 \%$ rise in ozone levels in summer compared to winter and monsoon months when solar insulation is week [15]. Overall, high levels of $\mathrm{O}_{3}$ associated in the high sunny periods, which are formed indirectly by the action of sunlight on nitrogen dioxide.

\subsection{Particulate Matter $\left(\mathrm{PM}_{10}\right)$}

Numerous epidemiological studies conducted over the past years indicate a strong association between ambient particulate matter concentrations and adverse health effects $[2,15] . \mathrm{PM}_{10}$ level varies in an enormous range of 4 - $1426 \mu \mathrm{g} / \mathrm{m}^{3}$. Seasonal mean average showed the highest values during summer and the lowest during winter (Figure 3). Daily average concentrations exceeded the permissible limit by 62,85 and 88 times during 2007 , 2008 and 2009 respectively. The high concentrations were due to natural phenomenon, the dusty and dry nature of the wind rising from the west and northwest. These winds were the result of dust storms that are typically originated by local desert and trans-boundary airborne effects coming from the southern Iraq desert impacting not only the entire region (Bahrain, Kuwait and eastern province of Saudi Arabia) but extending further into the Arabian Gulf [13]. Selected images of $\mathrm{PM}_{10}$ were obtained from the Moderate Resolution Imaging Spectroradiometer (Modis) for elevated level of $\mathrm{PM}_{10}$ during the period between 2007-2009 (Figure 4). Such study was also recommended in a regional published study. The

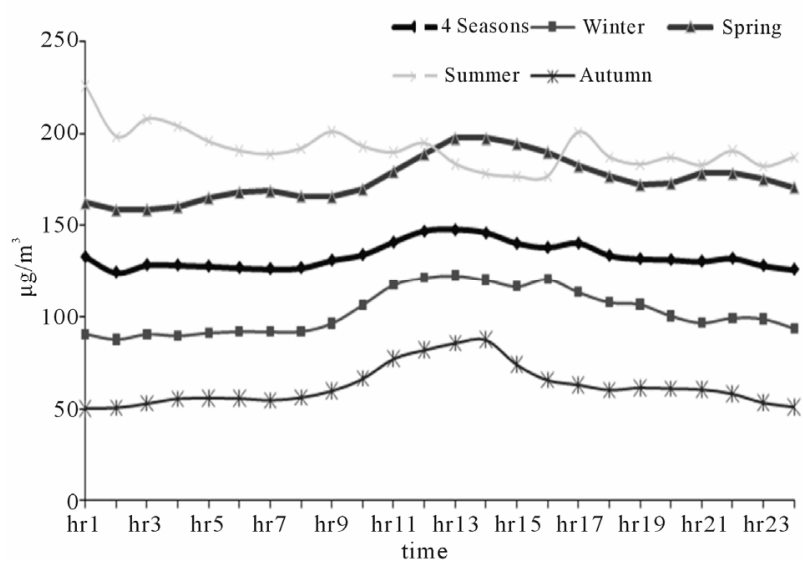

Figure 3. Diurnal and seasonal variation of $\mathrm{PM}_{10}$ during 2007-2009 from Al Mirfa city.
MODIS Rapid Response System was developed to provide daily satellite images of the earth's landmasses in near real time [16]. The images clearly demonstrated that the elevated levels of $\mathrm{PM}_{10}$ during the study period were associated with regional dust and sand storms. Such storms carry millions of tiny airborne particles and occur naturally in desert environments such as the UAE. Dust particles emitted by arid and semiarid regions make up about $45 \%$ of global aerosol emissions [17]. Construction activities can also stir up dust. Industrial processes such as fossil-fuel combustion in power plant are also sources of PM pollution.

The biggest hazard, according to the American researchers, is particulate matter-tiny particles of sand, dust and chemicals that can penetrate deep within the lungs. We have not enough information about the chemical composition and size of the floating particles, which has an effect on how dangerous they are, however high dust storm is natural phenomenon which may causes a considerable public health impact in the UAE [6]. Moreover, meteorological conditions plays a vital role in defining air quality in an area, either by dispersing and dissipating pollutants or aggravating air quality exceedances, therefore the ground level concentration of pollutants depends on the meteorological condition in the surrounding areas.

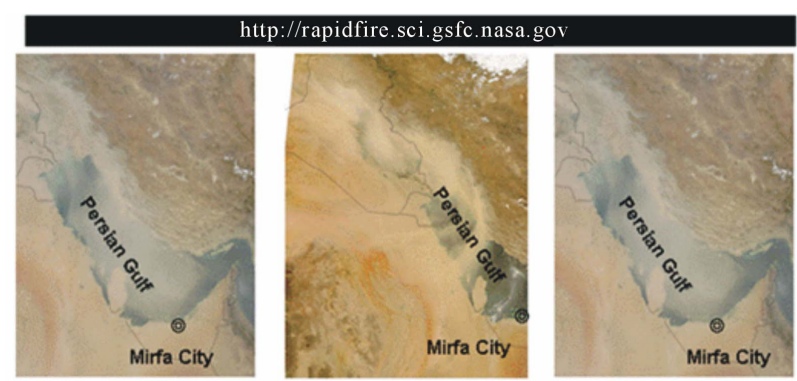

03 February $2007-0715$ Hrs 07 January 2008-0720 Hrs 31 July 2009-0705 Hrs

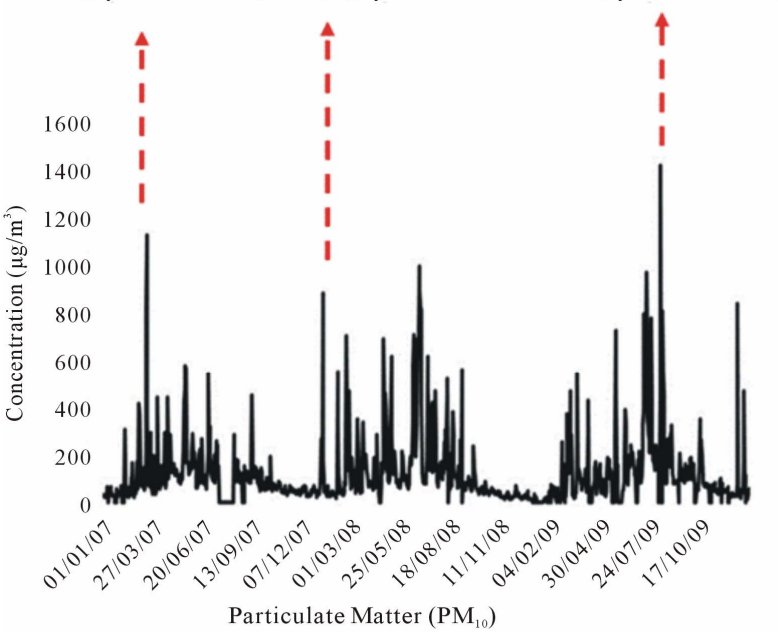

Figure 4. $\mathrm{PM}_{10}$ association with region sandstorms as evident in the MODIS Images during 2007-2009 from Al Mirfa city. 


\subsection{Metrological Conditions}

The predominant climatic condition in Al Mirfa area may be described as hot, dry, and sunny weather in summer; while winters are mild and humid, with occasional rain, temperature may fall to $6.4^{\circ} \mathrm{C}$ during night times. Summer seasons extend from 21 June to 20 September where the air is hot and dry, during 2007-2009; mean temperature during summer season was ranging from $35.09^{\circ} \mathrm{C}$ to $45.27^{\circ} \mathrm{C}$ with a mean temperature value of $33.52^{\circ} \mathrm{C}$. Relative humidity typically rises in summer season up to $>90 \%$. The recoded value during the study period reached a minimum of $6.77 \%$ in May, 2008 and a maximum of $98.75 \%$ in January, 2007. The lowest of which occurred in the afternoon, whereas the maximum value generally reported during early mornings. The prevailing wind direction recorded throughout the year was northwest (NW), since most of the winds were blown from directions between 292.5 and 337.5 degree, such type of winds characterize Abu Dhabi emirate conditions and are referred to as "Shamal" wind, it is also well known among other regions in the Arabian Gulf. Wind rose diagram for the whole period from 2007-2009 is presented in Figure 5 which matches to a great extent those seasonal wind roses. Wind speed diurnal plot shows the highest wind speed during all seasons is recorded at 16:00, the seasonal variation among wind speed is very slight, and more than $75 \%$ of the recorded speeds were between $0.5-4.7 \mathrm{~m} / \mathrm{s}$. The metrological parameters that are expected to affect the concentration of such pollutants as $\mathrm{NO}_{\mathrm{X}}$ and $\mathrm{SO}_{2}$ are wind speed and direction, mixing height, ambient temperature and inversion layer [11, $16,18,19]$. High wind speed wind is responsible for the effective ventilation of the air basin under specific condition (no thermal inversion). Whereas, sever temperature inversion is seen to be associated with high concentration of pollutants [18]. When the wind speed reaches its highest level, it helps reduce the concentration of air pollutants and, thus, serves to lower their hazardous effects. On the other hand, slow wind or calm conditions can give rise to build up high concentration in the immediate vicinity of the sources [18]. Improvement in air quality was observed in 2009 where weak negative $(r=-0.42)$ and insignificant $(r=0.03)$ correlations of winds were encountered with $\mathrm{NO}_{2}$ and $\mathrm{SO}_{2}$ respectively. It is logically accepted fact that when variation of wind speed does not considerable affect the concentration of gaseous pollutant, then one may conclude that such concentration is the background level of the region.

\subsection{Effective Measures for Pollution Reduction}

Natural gas is used as a primary fuel in all industrial facilities of Abu Dhabi Water and Electricity Authority

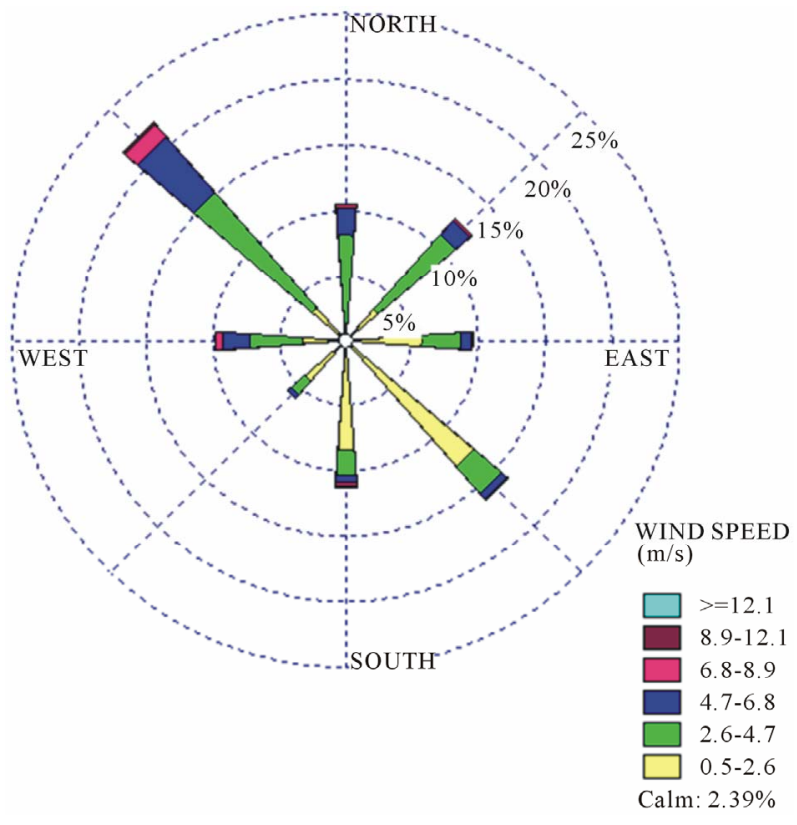

Figure 5. Wind rose in Al Mirfa during the years from 2007 to 2009.

(ADWEA's) power plants. This fuel is considered the cleanest among the fossil fuels releasing small amounts of sulfur dioxide and nitrogen oxides, virtually no ash or particulate matter, and lower levels of carbon dioxide, carbon monoxide, and other reactive hydrocarbons. ADWEA applies all possible and effective measures to achieve the minimum impact on the environment where gas fired power plants have low carbon emissions, air to fuel ratios are maintained at the optimal values to minimize emission concentration of carbon monoxide. As a reflection of governmental commitment toward the environmental protection, green (low sulphur content) fuels are used in the whole UAE leading to achieve negligible levels of sulpher dioxide in both emission sources and ambient atmosphere. Since the levels of ozone cannot be directly controlled, ADWEA's efforts have focused on controlling the emissions of the precursors that lead to $\mathrm{O}_{3}$ formation. Consequently, as the concentrations of VOCs emitted from power plants are already inconsiderable, low $\mathrm{NO}_{\mathrm{X}}$ burners are used to minimize the emission of $\mathrm{NO}_{\mathrm{X}}$ from combustion processes and eventually reduce the formation of ozone in the atmosphere. Regarding particulate matter, UAE experience elevated levels which are naturally originated by windblown desert sand and sea spray. Measures taken by ADWEA to protect human health are reflected by increase the capacity for air monitoring stations and assessing the impact on air quality through researches, where a network of seven ambient air quality monitoring stations has been established in addition to installing continuous emission measurement systems in the stationary sources of the plants. 


\section{Conclusions}

Following the continuous monitoring of the airborne pollutants and gases produced by the Al Mirfa power generation plant from 2007-2009, ADWEA determined that the air quality in Al Mirfa City was within FEA permissible limits, with the exception of $\mathrm{O}_{3}$ and $\mathrm{PM}_{10}$ levels. Observation from three years data summarized as follows:

- $\mathrm{NO}_{2}$ levels in $\mathrm{Al}$ Mirfa monitoring station compared with various worldwide suburban stations shows lowest concentration.

- Despite increasing in fuel combustion from 20072009, the mean level of CO decreased in 2009 indicating an improvement in air quality due to sustainable environmental measures taken in power plant operations.

- Low sulfur content fuels are used in all combustion facilities and appliances which resulted in negligible $\mathrm{SO}_{2}$ emissions in spite of increasing in fuel consumption from 2007-2009.

- Ozone hourly average concentrations exceeded FEA limit in many occasions. However, elevated levels of $\mathrm{O}_{3}$ are associated with high sunny periods where the pollutants are indirectly formed by the action of sunlight on nitrogen dioxide.

- Seasonal variation analysis reveals highest concentrations of $\mathrm{NO}_{2}$ and $\mathrm{SO}_{2}$ were recorded during winter, where summer months experienced highest concentrations of $\mathrm{CO}$ and $\mathrm{O}_{3}$.

- Wind speed does not considerably affect the concentrations of gaseous pollutants; and it may consider that such concentrations are the background levels of the region.

- $\mathrm{PM}_{10}$ daily concentrations violated standard limit in 235 occasions, the exceedances are due to natural phenomenon, which originated as a results of dust storms, from the typical nature of the local desert and trans-boundary airborne effects from southern Iraq desert that impacts almost entire Arabian Gulf. More studies on chemical nature are recommended for $\mathrm{PM}_{2.5}-\mathrm{PM}_{10}$. Seasonal variation shows high and low levels during summer and winter. Generally, the study area is characterized by good air quality even though some exceedances are occasionally recorded for $\mathrm{PM}_{10}$ and $\mathrm{O}_{3}$ pollutants. The primary and secondary particulates are usually originated by natural sources such as wind-blown sands and sea spray particles, on the other hand, ozone secondary pollutant are not emitted directly to the air and it is formed by the atmospheric photochemical reaction of $\mathrm{NO}_{\mathrm{X}}$ and VOCs in presence of sunlight.

\section{REFERENCES}

[1] M. A. Rodriguez, M. Carreras-Sospedra and D. Dabdub,
"Air Quality Impacts of Distributed Power Generation in the South Coast Air Basin of California 1: Scenario Development and Modeling Analysis," Atmospheric Environment, Vol. 40, No. 28, 2006, pp. 5508-5521. doi:10.1016/j.atmosenv.2006.03.054

[2] D. W. Dockery and C. A. Pope, "Acute Respiratory Effects of Particulate Air Pollution," Annual Reviews on Public Health, Vol. 15, 1994, pp. 107-132. doi:10.1146/annurev.pu.15.050194.000543

[3] J. Koenig and Q. Jane, "Health Effects of Ambient Air Pollution. How Safe Is the Air We Breathe?" Kluwer Academic Publishers, Dordrecht, 2000.

[4] C. A. Pope, R. T. Burnett, M. J. Thun, E. E. Calle, K. Krewski and G. D. Thurston, "Lung Cancer Cardio Pulmonary Mortality and Long-Term Exposure to Fine Particulate Air Pollution," Journal of American Medical Association, Vol. 287, 2002, pp. 1132-1141.

[5] P. Miller, et al., "Estimating Future Air Pollution from New Electric Power Generation Commission for Environmental Cooperation of North America," 2002. http://wwwcecorg/Storage/46/3838_2_airemissions-epdf

[6] “Air Pollution a Factor in Hundreds of Deaths," 2010. http://www.thenational.ae/news/uae-news/environment/ai r-pollution-a-factor-in-hundreds-of-deaths

[7] “Abu Dhabi Water and Electricity Company (ADWEC), United Arab Emirates," Annual Statistical Report, 2009.

[8] FEA, Council of Ministers, "Ambient Air Quality Standards, Air Pollutants Limits in the Ambient Air," 2006.

[9] EPA Clean Air Act, 2010. http://www.epa.gov/air/caa

[10] S. Pal Arya, "Air Pollution Meteorology and Dispersion," Oxford University Press, Oxford, 1999.

[11] M. Shahgedanova, "Carbon Monoxide and Nitrogen Oxides Pollution in Moscow," Water Air and Soil Pollution, Vol. 112, No. 1-2, 1999, pp. 107-131. doi:10.1023/A:1005043916123

[12] N. H. Thi and K. Ki-Hyun, "Changes in $\mathrm{NO}_{2}$ Concentration from Major Cities and Provinces in Korea: A Case Study from 1988 to 2003," Terrestrial Atmospheric and Oceanic Sciences Journal, Vol. 17, No. 1, 2006, pp. $277-$ 294.

[13] S. A. A. Khamdan, I. M. Al Madany and E. Buhussain, "Temporal and Spatial Variations of the Quality of Ambient Air in the Kingdom of Bahrain during 2007," Environmental Monitoring and Assessment, Vol. 154, 2009, pp. 241-252.

[14] H. Mayer, "Air Pollution in Cities," University of Freiburg, Freiburg, 1999.

[15] G. B Arifa and L. M. Mansha. "Development of Baseline Air Quality Data in Pakistan," Environmental Monitoring and Assessment, Vol. 127, No. 1-3, 2007, pp. 237-252. doi:10.1007/s10661-006-9276-8

[16] M. O. Andreae, "Climatic Effects of Changing Atmospheric Aerosol Levels," In: A. Henderson-Sellers, Ed., World Survey of Climatology, Elsevier, Amsterdam, 1995, pp. 341-392.

[17] Nasa's Earth Observing System. 
http://rapidfire.sci.gsfc.nasa.gov

[18] Al-Azmi, et al., " $\mathrm{SO}_{2}$ and $\mathrm{NO}_{\mathrm{X}}$ Emissions from Kuwait Power Station in Years 2001 and 2004 and Evaluation of the Impact of These Emissions on Air Quality Using Industrial Sources Complex Short-Term (ISCST) Model," Water, Air, and Soil Pollution, Vol. 203, No. 1-4, 2009, pp. 169-178.

[19] L. Dovile, "Nitrogen Dioxide and Their Relation with Meteorological Conditions and some Environmental Factors in Kaunas," Environmental Research, Engineering and Management, Vol. 1, No. 43, 2008, pp. 21-27. 